\title{
Four Times Monthly
}

National Cancer Institute

\section{Source}

National Cancer Institute. Four Times Monthly. NCI Thesaurus. Code C98852.

Four times per month. 